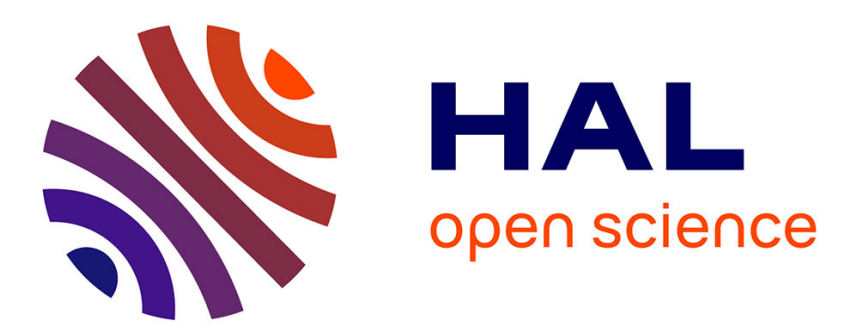

\title{
The earliest human occupation of North Africa: a reply toSahnouni et al. (2002)
}

Denis Geraads, Jean-Paul Raynal, Vera Eisenmann

\section{To cite this version:}

Denis Geraads, Jean-Paul Raynal, Vera Eisenmann. The earliest human occupation of North Africa: a reply toSahnouni et al. (2002). Journal of Human Evolution, 2004, 46, pp.751-761. 10.1016/j.jhevol.2004.01.008 . halshs-00003986

\section{HAL Id: halshs-00003986 \\ https://shs.hal.science/halshs-00003986}

Submitted on 7 Jul 2005

HAL is a multi-disciplinary open access archive for the deposit and dissemination of scientific research documents, whether they are published or not. The documents may come from teaching and research institutions in France or abroad, or from public or private research centers.
L'archive ouverte pluridisciplinaire HAL, est destinée au dépôt et à la diffusion de documents scientifiques de niveau recherche, publiés ou non, émanant des établissements d'enseignement et de recherche français ou étrangers, des laboratoires publics ou privés. 
To obtain a pdf version of this published manuscript for private use only, please contact the authors.

\title{
The earliest human occupation of North Africa: a reply to Sahnouni et al. (2002)
}

\author{
Denis Geraads $^{a}$, Jean-Paul Raynal ${ }^{b}$, Vera Eisenmann $^{c}$ \\ ${ }^{a}$ CNRS UPR 2147, 44 rue de l'Amiral Mouchez, 75014 Paris, France \\ ${ }^{\mathrm{b}} \mathrm{CNRS}$, IPGQ, UMR 5808, Bâtiment de Géologie, Avenue des facultés, Université de Bordeaux 1, 33405 \\ Talence cedex, France jpraynal@wanadoo.fr \\ 'UMR 5143 du CNRS,' Département Histoire de la Terre, Paléontologie, 8 rue Buffon, 75005 Paris,France
}

\section{Introduction}

In contrast to East Africa, which has a wealth of well-dated Plio-Pleistocene sites documenting human presence, North Africa has only a handful of localities that could have witnessed the first steps of our ancestors in this part of the continent, and their dating is conjectural. A long lithostratigraphic sequence is available only on the Moroccan Atlantic coast in the Casablanca area, where it covers the whole Pliocene and Pleistocene (Lefèvre and Raynal, 2002; Texier et al., 2002). Lack of datable volcanic material has prevented the use of most radiometric dating techniques. Up to now, absolute dating has been obtained by optically stimulated luminescence (OSL) at several sites of the Sidi Abderrahman quarries and at the early Pleistocene Thomas Quarry site (Raynal et al., 2002), and by electron spin resonance (ESR) at the middle Pleistocene site of "Grotte des Rhinocéros" (Rhodes et al., 1994). Therefore, dating must rely mostly on biochronology, but, pending discovery of many more fossiliferous localities, the accuracy of the North African framework will remain imperfect relative to the East African one. In a series of papers, Sahnouni et al. $(1996,2002)$ and Sahnouni and de Heinzelin (1998) have reported the results of their renewed excavations at the important Algerian localities of Ain Hanech and Aïn Boucherit, first studied by Arambourg (e.g., Arambourg, 1970, 1979). According to the latest paper by Sahnouni and co-workers (Sahnouni et al., 2002), Aïn Hanech would belong to the Olduvai subchron, dated to $1.77-1.95 \mathrm{Ma}$. This would make it by far the earliest North African site with evidence of hominid presence, and the time-equivalent of Olduvai Bed I, circum-KBS tuff levels at Koobi Fora, and Omo Shungura Member H. However, a review of the evidence put forward by Sahnouni et al. (2002) casts doubt on their conclusions. This evidence consists of 1) paleomagnetism, 2) biochronology, and 3) archaeology. They are discussed in this order below, preceded by a review of the more continuous Moroccan Atlantic sequence.

\section{The age of the earliest North African occupation sites}

At the present time, two stages relevant to human prehistory in this area can be distinguished in Morocco: before and after the occurrence of hominids.

\section{Before documented hominid immigration}

Ahl al Oughlam is by far the richest fossiliferous locality of this time period in North Africa, and second only to the Fayum for the whole Cenozoic. It is a karst and fissure filling in calcareous sandstones, formerly believed to be of Pleistocene age. Only biochronological dating is possible, and this provides an age of ca. $2.5 \mathrm{Ma}$ (Geraads et al., 1998, and references therein). 
The site has yielded no paleontological or archaeological evidence of hominid presence, despite the richness of the site (more than 4000 identifiable bones belonging to 41 large mammal species). This can probably be taken as evidence of hominid absence, because no such rich site of similar age in eastern or southern Africa is completely devoid of hominid remains.

\section{After hominid immigration}

Layer L of Thomas Quarry (Raynal et al., 2001) has yielded a rich early Acheulean industry that is associated with a small faunal assemblage. The latter has only a few diagnostic elements (Raynal et al., 2001, 2002; Geraads, 2002), but is quite distinct from the faunas of the later middle Pleistocene sites of the same quarry, and from that of the well-known site of Tighenif, of early middle Pleistocene age (Geraads et al., 1986). Therefore, Layer L must be significantly earlier than Tighenif. The occurrence of the murid rodent Paraethomys cf. mellahe, previously known at Oued Mellah (a site assigned to the early Pleistocene by Ameur, 1988), and of a primitive Acheulean industry, permits an age estimate of between 1.0 and $1.5 \mathrm{Ma}$. This age is in good agreement with the results of OSL dating.

If the absence of hominids at Ahl al Oughlam is taken at face value, then hominid immigration into the Maghreb took place during the gap between ca. $2.5 \mathrm{Ma}$ and ca. $1.2 \mathrm{Ma}$, and any site that samples this period of time deserves special attention.

Aïn Boucherit in Algeria (Arambourg, 1970, 1979) is younger than Ahl al Oughlam on biochronological grounds. Aïn Hanech, which is stratigraphically above Aïn Boucherit, is another important locality of this time period. There, Arambourg discovered and published (Arambourg, $1970,1979)$ a fauna that he referred to the "Villafranchien supérieur," associated with spheroid artifacts. Recently, the site has been referred by Sahnouni et al. (2002) to the earliest Pleistocene. We question their inferences on the following grounds.

\section{Paleomagnetism}

According to Sahnouni et al. $(1996,2002)$ and Sahnouni and de Heinzelin (1998), the Aïn Boucherit strata have a reversed polarity, whereas those of Ain Hanech have a normal one. They conclude that since the Ain Hanech fauna is certainly too old to be of middle Pleistocene age, this normal period cannot be the Brunhes epoch, but is "most likely" the Olduvai subchron. Several points must be made here:

1. No detail on the experimental procedure or polarity data has ever been published to support these reported results. The reader is just left with "normal/reverse." Such a result, given the detritic nature of the sediments, should be taken with utmost caution.

2. No mention is made of the Jaramillo event, dated to ca. 1.0 Ma. Even though it is of short duration, the possibility that sediments with a normal polarity belong to this interval should not be ruled out.

3. In short sedimentary sequences such as the one at Ain Hanech, paleomagnetism cannot be understood without a framework provided by another dating method, such as biochronology (see discussion in Pickford, 1997). It can only refine the results of the latter, but cannot take precedence over them.

Use of paleomagnetic data in continental deposits is a difficult and risky task, and all precautions should be taken before conclusions are drawn. We do not believe that the paleomagnetic data published up to now on Aïn Hanech and Aïn Boucherit contribute definitively to the dating of these sites.

\section{Biochronology}

Aïn Boucherit has only a few taxa of biochronological value, but the presence of Equus and the 
very different nature of the faunal associations, especially bovids, show that it is significantly younger than Ahl al Oughlam, whose bovids, by comparison with those from east African sites, indicate a late Pliocene age (Geraads and Amani, 1998). Aïn Boucherit has the alcelaphine bovid Parmularius altidens, which is similar to that of Olduvai Bed I and KBS member of Koobi Fora, both dated to less than $2.0 \mathrm{Ma}$. Oreonagor is represented by a form definitely more derived than that of the late Pliocene site of Ain Jourdel. Anancus is the only form suggesting a Pliocene age, but it persists until about $2.0 \mathrm{Ma}$ in Europe (Chilhac) and South Africa (Baard's Quarry). Nothing proves that Ain Boucherit is older than 2.0 Ma. Sahnouni et al.'s (Sahnouni et al., 2002, Fig. 1) dating of this site at $2.32 \mathrm{Ma}$ is thus highly conjectural.

The fauna from Aïn Hanech itself is very different from that of Aïn Boucherit, and must be significantly younger. First, it lacks several taxa that are present in the underlying Aïn Boucherit level: Anancus, Hipparion, and the primitive antelopes Oreonagor and Parantidorcas. Some of these absences could have a taphonomic origin, but its few key fossil species also point to a much younger age. Elephas moghrebiensis looks very much like E. recki ileretensis, a derived stage of the species (Geraads and Metz-Muller, 1999); according to the most recent revision, the range of this subspecies covers most of the early Pleistocene (Todd, 2001: Fig. 1). Although given a new name by Arambourg (1979), the oryx is Oryx gazella, with antero-posteriorly compressed horn-cores, a derived feature known at Tighenif (Geraads, 1981) but unknown in the Plio-Pleistocene of the Turkana basin. Other than Ain Hanech, Numidocapra has been found only at Anabo Koma in Djibouti, a site dated to ca. 1.6 Ma (de Bonis et al., 1988), and at Bouri Daka in the Middle Awash, dated to ca. 1.0 Ma (Vrba, 1997). Sivatherium is known since the early Pliocene but persists at Olorgesailie (ca. 0.8-1.0 Ma). Crocuta crocuta is much closer to the middle Pleistocene $C$. crocuta from Tighenif, the middle and late Pleistocene $C$. crocuta spelaea, and the living form than to earlier Crocuta, including the large South African early Pleistocene ones (Fig. 1). Thus, from these few elements, the "best fit" of Ain Hanech is around $1.2 \mathrm{Ma}$ (Fig. 2).

Much of the purported evidence provided by Sahnouni et al. (2002) for an early age of Aïn Hanech rests upon their interpretation of the remains of Equus and the suid Kolpochoerus. Contrary to Sahnouni et al. (2002), quoting Bernor and Armour-Chelu (1999), it is not true that the first occurrence (FAD) of Equus in East Africa is at $2.36 \mathrm{Ma}$. As previously established (Eisenmann, 1976; Hooijer, 1976), it is in unit G1 of Member G (not F) of the Shungura formation, Omo Basin, Ethiopia. R. Bernor and F. Clark Howell (in litt., pers. comm.) confirmed that there is no Equus in Member $F$. The difference in time is small since the dates for Tuffs $F$ and $G$ are very close: $2.360 .05 \mathrm{Ma}$ for $\mathrm{F}$ and $2.330 .03 \mathrm{Ma}$ for $\mathrm{G}$ (Brown et al., 1985, Brown and Feibel, 1991), but it is noteworthy because although the material from Member $F$ is reasonably rich, it contains not one single specimen of Equus. Moreover, there is some change at that time in the size and morphology of Omo Hipparion cheek teeth (Eisenmann, 1985b: Fig. 1-2), suggesting change towards a less dry diet (Eisenmann and Bonnefille, 1979). Bernor and Armour-Chelu (1999) also documented an increase in Hipparion crown height.

The other early occurrences of Equus in Africa are not dated. According to our personal observations in South Africa (not published), Equus is absent at Makapansgat but present at the Sterkfontein site. In North Africa, an Equus, probably Equus stenonis (Eisenmann, 1999, 2002), is present at Aïn Jourdel (Table 1). Sahnouni et al. (2002: 930) stated that E. numidicus, which is present in Aïn Boucherit, persists in Aïn Hanech. This assertion is founded on a lower P4, which "although metrically close to $E$. tabeti in is maximal dimensions, morphologically resembles $E$. numidicus from Ain Boucherit." Thus, a possibly larger tooth than the usual teeth of $E$. tabeti (described at Ain Hanech) would be evidence of the persistence in younger levels of E. numidicus, an older and larger species (described in Aïn Boucherit).

In our experience (Eisenmann, 1981), equid lower cheek tooth size and morphology are seldom diagnostic at the specific level. When a single specimen is discussed, even more caution is needed because in any large sample there are specimens with "atypical" (for the sample) 
morphologies. "Resembles" does not mean "is." However, the lower premolar figured by Sahnouni et al. (2002), Fig. 3) does not resemble the premolar figured by Arambourg (1970: Pl. 20, Fig. 8) - the only one collected at Aïn Boucherit to our knowledge. At Aïn Boucherit, the linguaflexid is deep and pointed, the metaconid and metastylid are both round and symmetrical, and the isthmuses have a zebrine pattern (using the terminology of Skinner, 1972: Figs. 57-58). In the premolar illustrated by Sahnouni et al., the linguaflexid is shallow, the metaconid is pyriform and larger than the metastylid, and the isthmuses pattern is hemionid. Some "atypical" teeth from Tighenif display the same morphology. The size of the lower premolar from Ain Hanech cannot be discussed because the authors give no measurements to compare with those of E. tabeti (Eisenmann, 1981: Table 23) or E. numidicus (Eisenmann, 1981: Table 26). But the question of a second species at Ain Hanech, larger than $E$. tabeti, must also take into account other fossils "atypical" for E. tabeti. In the sample of Aïn Hanech, there are at least four upper cheek teeth too large to belong to E. tabeti: two premolars (HAN 917 and 989) and two molars (HAN 827 and 866 ). The scatter diagram (Fig. 3) of protocone length versus the most reliable occlusal dimension, i.e., the mean of length+width (Eisenmann, 2003), shows a considerable overlap between E. numidicus of Aïn Boucherit, E. tabeti of Aïn Hanech, and E. mauritanicus of Tighenif. According to size and protocone length, the large upper cheek teeth from Aïn Hanech could belong to $E$. numidicus, E. mauritanicus, or any other species of large size. However, the presence of a large and flat mesostyle in HAN 989 (broken in HAN 917) argues against its referral to E. numidicus, in which the mesostyle is small (Arambourg, 1970: PI. 19, Fig. 6-7). At Tighenif, large and flat mesostyles are uncommon but do exist (in at least seven premolars). The above caution about specific referral of lower cheek teeth applies also to upper ones: we cannot say to what species the large teeth of Ain Hanech belong, but there is no particular reason to refer them to $E$. numidicus (contra Eisenmann, 1980).

Fortunately, limb bones, and third metacarpals in particular, are far more reliable than teeth, at least when the problem of discrimination concerns a limited number of species within a limited geographic area. Third metacarpals (MC III) of E. numidicus and E. tabeti are characterized by their large size, slenderness, and depth (Table 1;

Eisenmann, 1987: Fig. 2), those of $E$. tabeti being smaller and slenderer. At Tighenif, most MC III (Table 1, Fig. 4: mean of E. mauritanicus) are short, robust, and flat in the diaphysis and at the distal end. Occasionally (Fig. 4: TER 356) they may be deep in the diaphysis but the distal end remains flat. At Aïn Hanech, Arambourg (1970:

114) noted the occurrence of a "zebralike" MC III and there is yet another one that cannot belong to E. tabeti. Their numbers are HAN 3 and 4. The ratio diagram (Fig. 4) shows that HAN 3 resembles TER 356 in size and proportions, while HAN 4 resembles more the average $E$. mauritanicus. Both are within the range of variation for the latter species. Therefore, the evidence provided by the metacarpals - which is presently the most reliable evidence-points to the presence at Aïn Hanech of a "zebralike" E. cf. mauritanicus, certainly not E. numidicus.

Slender third metapodials resembling $E$. numidicus and/or E. tabeti occur in Member G (middleupper and G5) and Member H (lower) of the Shungura Formation, Omo Basin, Ethiopia; in Olduvai Bed I (Eisenmann, 1985a); and at Ubeidiyeh, Israel (Eisenmann, 1987). Third metapodials of average robustness are also very common but none can safely be referred to $E$. mauritanicus. Therefore, there is no definite record of this species before the late early Pleistocene. The East and North African Equus have been compared, documented, and discussed in various papers. Data on skulls, teeth, and third metapodials can be found in Eisenmann (1979, 1980, 1981, 1983, 1985b, 1987, 2003; Eisenmann and Karchoud, 1982); ratio diagrams comparing third metapodials in Eisenmann (1985a); discussion of early monodactyl equid limb bones in Eisenmann (1999, 2002); and discussion of skull differences in Eisenmann and Baylac (2000). In spite of this, our understanding and knowledge of Pleistocene equids remain very poor and we must stress that chronological inferences based on one Equus tooth should be examined with great care. In their analysis of the suid Kolpochoerus, Sahnouni et al. 
(2002) use the "stage of evolution" (in fact, mainly the length) of the poorly preserved lower M3 to infer an age close to the KBS tuff (ca. 1.8 Ma; Brown and Feibel, 1991) because this length is intermediate between those of the Kolpochoerus M3s from the Notochoerus scotti and the Metridiochoerus andrewsi zones at Koobi Fora. The " $N$. scotti zone" corresponds to the Upper Burgi member, while the " $M$. andrewsi zone" corresponds to the KBS member of the Koobi Fora Formation. They are separated by a signifi-cant stratigraphic gap below the KBS tuff (Brown and Feibel, 1991).

Several comments should be made here. The use of suid evolutionary changes in biochronology has perhaps been over-emphasized in East Africa, to the point that one might believe that a tooth provides a date. The fact that the length of the tooth from Aïn Hanech falls between the means of Upper Burgi Member and KBS Member teeth should not hide the fact that it also falls within the ranges for the teeth from both of these members, as well as within the range for the teeth from the still younger Okote member (Fig. 5). In any case, the East African suid biochronology is certainly not directly applicable to North Africa, since the species are different. Recent excavations in Layer $L$ of Thomas Quarry in Morocco has yielded a Kolpochoerus upper M3 very similar to that of $K$. maroccanus, a species described by Ennouchi (1953) based on an upper P4 and an upper M3 of unknown age. The lower M3 of this species is unknown, but the possibility that it is similar to that of Ain Hanech should be considered, especially because the latter tooth, although longer, is simplified relative to the lower M3 of $K$. phacochoeroides from Ahl al Oughlam (Geraads, 1993), just as the upper M3 of K. maroccanus is simplified relative to those of the latter site. Whether or not the Thomas $L$ and Ain Hanech Kolpochoerus are of the same species remains to be demonstrated, but the Thomas $L$ fossil definitely extends the range of this genus in North Africa into the late early Pleistocene.

To sum up, the evolution of Kolpochoerus in North Africa is still imperfectly understood, and it is certainly unwise to draw any definite biochronological conclusions from a single tooth. Until the evolution of this genus in this part of the continent becomes better known, the only definite indication provided by its occurrence at Aïn Hanech is earlier than middle Pleistocene.

\section{Archaeology}

Assemblages of Levels A and B at Aï Hanech and from El-Kherba are considered by Sahnouni et al. (2002) as Oldowan on the basis of their composition: cores, core-forms, and flakes. In fact, these assemblages do not really differ from Oldowan-like assemblages from Thomas Quarry 1 Layer $L$, where the lithic assemblages discovered in the different units exhibit a high degree of variation, with an alternation of industries rich or poor in bifacial pieces, i.e., Acheulean-like or Oldowanlike assemblages: cores (some with a preferential and radial organization) and corelike tools with numerous flakes in Unit L5, above the typical early Acheulean of Unit L1 with bifaces, cleavers, spheroids, various choppers, various polyhedrons, and flakes. This situation is not unique: very old Acheulean artifacts are known at ca. $1.5 \mathrm{Ma}$ in Ethiopia at Konso-Gardula (Asfaw et al., 1992) and ca. 1.0 Ma at Kesem-Kebena (WoldeGabriel et al., 1992). On the other hand, Oldowan assemblages can be relatively young, such as at NY 18 in Uganda, dated to 1.5 $\mathrm{Ma}$, where artifacts are very similar to the industry of Thomas Quarry 1 Unit L5 (Texier, 1995), or even much younger, as at Bodo, where Oldowan assemblages are dated to ca. $0.64 \mathrm{Ma}$ (Clark et al., 1994).

Some factors of variation might have a natural origin, such as selection of materials by redeposition, which has taken place in some levels of Thomas Quarry 1. For example, in Unit L1, where small flakes and bone fragments have been washed away or concentrated, the fabric (orientation and position) of bigger artifacts clearly indicates a water-flow action. On the other hand, the smallest flakes are preserved in eolian sands of Unit L5. Possible cultural reasons for this variability among Acheulean assemblages must also be considered. When not due to the nature of the raw material, the variation may be connected with peculiar functional situations, 
such as hominid adaptive reactions to environmental and/or microenvironmental changes resulting from limited or global climatic changes, as pointed out in East Africa at Olorgesailie (Isaac, 1966, 1977), Kilombe (Gowlett, 1988), and Bodo (Clark et al., 1994). Evidence for such variation in assemblages according to environmental or climatic fluctuations within a short time span is illustrated by Units L5 and L1 of Layer $L$ at Thomas Quarry 1. Furthermore, the limited area of excavations is certainly an important factor of the observed variability.

Up to now, if we accept the variability within a single Acheulean complex, and in spite of almost a century of archaeological excavations, there is still no Oldowan site identified in Morocco. Indeed, the lithic assemblages taken by Biberson (1961) as "stages I and IV" of the Moroccan pebbleculture are either geofacts (at Ahl al Oughlam) or reworked MSA assemblages rich in pebble-tools (Raynal and Texier, 1989). Moreover, "Oldowan" assemblages discovered near Rabat (Biberson, 1961) turned out to be late Acheulean (El Hajraoui, 1985) or even Aterian (Texier, 1986).

Both are rich in pebble-tools but poor in diagnostic artifacts (bifaces or pedunculates). The use of a so-called simple technology by hominids is certainly neither a univocal indicator of high antiquity nor a deciding factor of cultural affinity.

\section{Conclusion}

Hominid immigration into North Africa probably took place between 2.5 and $1.2 \mathrm{Ma}$, but secure dating of the sites belonging to this period is still lacking. Ain Hanech is certainly one of the best candidates to be the earliest occupation site in the Maghreb, but arguments for putting it earlier than Layer $L$ of Thomas Quarry are not at this time fully convincing.

\section{Acknowledgements}

Our best thanks to Ray Bernor and Bill Kimbel, whose comments greatly improved the manuscript.

\section{References}

Ameur, A., 1988. Biochronologie des formations continentales du Néogène et du Quaternaire d'Algérie. Contribution des micromammifères. Unpublished Thesis, University of Oran.

Arambourg, C., 1970. Les Vertébrés du Pléistocène de l'Afrique du Nord. Arch. Mus. Nat. hist. nat. 10, 1-127. Arambourg, C., 1979. Vertébrés villafranchiens de l'Afrique du Nord (artiodactyles, carnivores, primates, reptiles, oiseaux). Fondation Singer-Polignac, Paris.

Asfaw, B., Beyene, Y., Suwa, G., Walter, R.C., White, T.D., WoldeGabriel, G., Yemane, T., 1992. The earliest Acheulean from Konso-Gardula. Nature 360, 732-735.

Bernor, R., Armour-Chelu, M., 1999. Family Equidae. In: Rössner, G.E., Heissig, K. (Eds.), The Miocene Land Mammals of Europe. Pfeil, München, pp. 193-202.

Biberson, P., 1961. Le cadre paléogéographique de la préhistoire du Maroc atlantique. Publ. Serv. Antiq. Maroc 16, $1-235$.

Brown, F.H., Feibel, C.S., 1991. Stratigraphy, depositional environments, and palaeogeography of the Koobi Fora Formation. In: Harris, J.M. (Ed.), Koobi Fora Research Project, Vol. 3. The Fossil Ungulates: Geology, Fossil Artiodactyls, and Palaeoenvironments. Clarendon Press, Oxford, pp. 1-30.

Brown, F.H., McDougall, I., Davies, T., Maier, R., 1985. An integrated Plio-Pleistocene chronology for the Turkana Basin. In: Delson, E. (Ed.), Ancestors: The Hard Evidence. Alan R. Liss, New York, pp. 82-90.

Clark, J.D., de Heinzelin, J., Schick, K.D., Hart, W.K., White, T.D., WoldeGabriel, G.,Walter, R.C., Suwa, G., Asfaw, B., Vrba, E., Selassié, Y.H., 1994. African Homo erectus: old radiometric ages and young Oldowan assemblages in the Middle Awash Valley, Ethiopia. Science 264, 1907-1910.

Cooke, H.B.S., 1976. Suidae from Plio-Pleistocene strata of the Rudolf basin. In: Coppens, Y., Howell, F.C., Isaac, G.L., Leakey, R.E.F. (Eds.), Earliest Man and Environments in the Lake Rudolf Basin. University of Chicago Press, Chicago, pp. 251-263.

de Bonis, L., Geraads, D., Jaeger, J.-J., Sen, S., 1988. Vertébrés pléistocènes de Djibouti. Bull. Soc. Géol. Fr. 4(sér. 8), 323-334.

Eisenmann, V., 1976. Equidae from the Shungura Formation. In: Coppens, Y., Howell, F.C., Isaac, G.L, Leakey, R.E.F. (Eds.), Earliest Man and Environments in the Lake Rudolf Basin. University of Chicago Press, Chicago, pp. 225-233. 
Eisenmann, V., 1979. Les métapodes d'Equus sensu lato (Mammalia, Perissodactyla). Géobios 12, 863-886.

Eisenmann, V., 1980. Les Chevaux (Equus sensu lato) fossiles et actuels: crânes et dents jugales supérieures. Cahiers de Paléontologie du CNRS, Paris.

Eisenmann, V., 1981. Etude des dents jugales inférieures des Equus actuels et fossiles. Palaeovertebrata 10, 127226.

Eisenmann, V., 1983. Family Equidae. In: Harris, J.M. (Ed.), Koobi Fora Research Project, Vol. 2. The Fossil Ungulates: Proboscidea, Perissodactyla and Suidae. Clarendon Press, Oxford, pp. 156-214.

Eisenmann, V., 1985a. Indications paléoécologiques fournies par les Equus (Mammalia, Perissodactyla) Pliocènes et Pléistocènes d'Afrique. L'environnement des Hominidés au Plio-Pléistocène. Coll. Fondation Singer-Polignac, Masson, Paris, pp. 57-79.

Eisenmann, V., 1985b. Les Equidés des gisements de la vallée de l'Omo en Ethiopie (collections françaises). Cahiers de Paléontologie, Travaux de Paléontologie est-africaine, CNRS, Paris, pp. 13-55.

Eisenmann, V., 1987. Les Equidés d’Oubeidiyeh. Mém. Trav. Centre Rech. Fr. Jérusalem 5, 191-212.

Eisenmann, V., 1999. Equus granatensis of Venta Micena and evidence for primitive non-stenonid horses in the lower

Pleistocene. In: Gilbert, J., Sanchez, E., Gilbert, L., Ribot, E. (Eds.), Proceedings of the International Conference of Human Palaeontology Orce 1995: The Hominids and Their Environment During the Lower and Middle Pleistocene of Eurasia. Museo de Prehistoria Paleontologia, Orce, pp. 175-189.

Eisenmann, V., 2002. The primitive horses of the Vatera Formation (Lesbos, Greece). In: Proceedings of the 1st International Workshop On Late Plio/Pleistocene Extinction and Evolution in the Palearctic: The Vatera Site. Ann. Géol. Pays Hellén 1ère sér. 39 (A), 131-153.

Eisenmann, V., 2003. Gigantic horses. In: Petculescu, A., Stiuca , E. (Eds.), Advances in Paleontology. Hen to Panta: Papers in Honour of Constantin Radulescu and Petre Mihai Samson. Em'il Racovitza , Institute of Speleology, Bucharest, pp. 31-40.

Eisenmann, V., Baylac, M., 2000. Extant and fossil Equus (Mammalia, Perissodactyla) skulls: a morphometric definition of the subgenus Equus. Zoologica Scripta 29, 89-100.

Eisenmann, V., Bonnefille, R., 1979. Les dents d' Hipparion, les analyses polliniques et le paléoenvironnement. 7ème Réunion Ann. Sc. Terre, Lyon, 1979, Soc. géol. Fr., 178.

Eisenmann, V., Karchoud, A., 1982. Analyses multidimensionnelles des métapodes d' Equus. Bull. Mus. natn. Hist. nat., Paris, C 4ème sér 4, 75-103.

El Hajraoui, A. Les industries préhistoriques de la région de la Mamora dans leur contexte géologique et paléopédologique. Thèse Univ. Bordeaux 1, no 2056

Ennouchi, E., 1953. Omochoerus maroccanus nov. sp., nouveau Suidé marocain. Bull. Soc. Géol. Fr. 6, 649-656.

Geraads, D., 1981. Bovidae et Giraffidae (Artiodactyla, Mammalia) du Pléistocène de Ternifine (Algérie). Bull. Mus. natn. Hist. nat., Paris, C 4ème sér 3, 47-86.

Geraads, D., 1993. Kolpochoerus phacochoeroides (Thomas, 1884) (Suidae, Mammalia), du Pliocène supérieur de Ahl al Oughlam (Casablanca, Maroc). Géobios 26, 731-743.

Geraads, D., 2002. Plio-Pleistocene mammalian biostratigraphy of Atlantic Morocco. Quaternaire 13, $43-53$.

Geraads, D., Amani, F., 1998. Bovidae (Mammalia) du Pliocène final d'Ahl al Oughlam, Casablanca, Maroc. Paläont. Z. 72, 191-205.

Geraads, D., Amani, F., Raynal, J.-P., Sbihi-Alaoui, F.-Z., 1998. La faune de Mammifères du Pliocène terminal d'Ahl al Oughlam, Casablanca, Maroc. C. r. Acad. Sci., Paris sér. Ila 326, 671-676.

Geraads, D., Hublin, J.-J., Jaeger, J.-J., Tong, H., Sen, S., Toubeau, P., 1986. The Pleistocene hominid site of Ternifine, Algeria: new results on the environment, age and human industries. Quatern. Res. 25, 380-386.

Geraads, D., Metz-Muller, F., 1999. Proboscidea (Mammalia) du Pliocène final d'Ahl al Oughlam (Casablanca, Maroc). N. Jb. Geol. Paläont. Mh. 1999, 52-64.

Gowlett, J.A.J., 1988. A case of developed Oldowan in the Acheulean? World Archaeol. 20, 13-26.

Harris, J.M., 1983. Family Suidae. In: Harris, J.M. (Ed.), Koobi Fora Research Project, Vol. 2. The Fossil Ungulates: Proboscidea, Perissodactyla and Suidae. Clarendon Press, Oxford, pp. 215-302.

Hendey, Q.B., Cooke, H.B.S., 1985. Kolpochoerus paiceae (Mammalia, Suidae) from Skurwerug, near Saldanha, South Africa, and its palaeoenvironmental implications. Ann/s. S. Afr. Mus. 97, 9-56.

Hooijer, D.A., 1976. Evolution of the Perissodactyla of the Omo group deposits. In: Coppens, Y., Howell, F.C., Isaac, G.L, Leakey, R.E.F. (Eds.), Earliest Man and Environments in the Lake Rudolf Basin. University of Chicago Press, Chicago, pp. 209-213.

Isaac, G.L., 1966. New evidence from Olorgesailie relating to the character of Acheulian occupation sites. In: Cuscoy, L.D. (Ed.), Actas del V Congreso Panafricano de Prehistoria y de Estudio del Cuaternario. Publicaciones del Museo Arqueologico Santa Cruz de Tenerife, Tenerife 6, pp. 135-145.

Isaac, G.L., 1977. Olorgesailie: Archaeological Studies of a Middle Pleistocene Lake Basin in Kenya. University of Chicago Press, Chicago.

Lefèvre, D., Raynal, J.-P., 2002. Les formations Plio-Pléistocènes de Casablanca et la chronostratigraphie du Quaternaire marin du Maroc revisitées. Quaternaire 13, 9-21.

Pickford, M., 1997. Reply to Van der Made, 1995. Paleontologia I'Evolucio' 30-31, 269-274.

Raynal, J.-P., Sbihi-Alaoui, F.-Z., Geraads, D., Magoga, L., Mohib, A., 2001. The earliest occupation of North-Africa: 
the Moroccan perspective. Quatern. Int. 75, 65-75.

Raynal, J.-P., Sbihi-Alaoui, F.-Z., Magoga, L., Mohib, A., Zouak, M., 2002. Casablanca and the earliest occupation of North Atlantic Morocco. Quaternaire 13, 65-77.

Raynal, J.-P., Texier, J.-P., 1989. Découverte d'Acheuléen ancien dans la carrière Thomas I a' Casablanca et problème de l'ancienneté de la présence humaine au Maroc. C. r. Acad. Sci., Paris sér. Ila 308, 1743-1749.

Rhodes, E., Raynal, J.-P., Geraads, D., Sbihi-Alaoui, F.-Z., 1994. Premières dates RPE pour l'Acheuléen du Maroc Atlantique (Grotte des Rhinocéros, Casablanca). C. r. Acad. Sci., Paris sér. Ila 319, 1109-1115.

Sahnouni, M., de Heinzelin, J., 1998. The site of Aïn Hanech revisited: new investigations at this lower Pleistocene site in northern Algeria. J. Archaeol. Sci. 25, 1083-1101.

Sahnouni, M., de Heinzelin, J., Brown, F., Saoudi, Y., 1996. Récentes recherches dans le gisement oldowayen d'Aïn Hanech, Algérie. C. r. Acad. Sci., Paris sér. Ila 323, 639-644.

Sahnouni, M., Hadjouis, D., van der Made, J., Derradji, A., Canals, A., Medig, M., Belahrech, H., Harichane, Z., Rabhi, M., 2002. Further research at the Oldowan site of Aïn Hanech, north-eastern Algeria. J. hum. Evol. 43, 925937.

Skinner, M.F., 1972. Perissodactyla. In: Skinner, M.F., Hibbard, C.W. (Eds), Early Pleistocene Preglacial and Glacial Rocks and Faunas of North-Central Nebraska. Bulletin of the American Museum of Natural History 148, 117130.

Texier, J.P., 1986. Le site atérien du Chaperon Rouge I (Maroc) et son contexte géologique. Bull. Archéol. Maroc 16, 27-73.

Texier, P.J., 1995. The Oldowan assemblage from NY 18 site at Nyabusosi (Toro-Uganda). C. r. Acad. Sci., Paris sér. Ila 320, 647-653.

Texier, J.-P., Lefèvre, D., Raynal, J.-P., El Graoui, M., 2002. Lithostratigraphy of the littoral deposits of the last one million years in the Casablanca region (Morocco). Quaternaire 13, 23-41.

Todd, N., 2001. African Elephas recki: time, space and taxonomy. In: Cavarretta, G., Gioia, P., Mussi, M., Palombo, M.R. (Eds.), The World of Elephants, Proceedings of the 1st International Congress. Consiglio Nazionale delle Ricerche, Rome, pp. 693-697.

Turner, A., 1984. The interpretation of variation in fossil specimens of spotted hyaena (Crocuta crocuta Erxleben, 1777) from Sterkfontein valley sites. Annls. Transv. Mus. 33, 399-418.

Vrba, E., 1997. New fossils of Alcelaphini and Caprinae (Bovidae: Mammalia) from Awash, Ethiopia, and phylogenetic analysis of Alcelaphini. Palaeont. afr. 34, 127-198.

WoldeGabriel, G., White, T., Suwa, G., Semaw, S., Beyene, Y., Asfaw, B., Walter, R., 1992. Kesem-Kebena: a newly discovered paleoanthropological research area in Ethiopia. J. Field Archaeol. 19, 471-493.

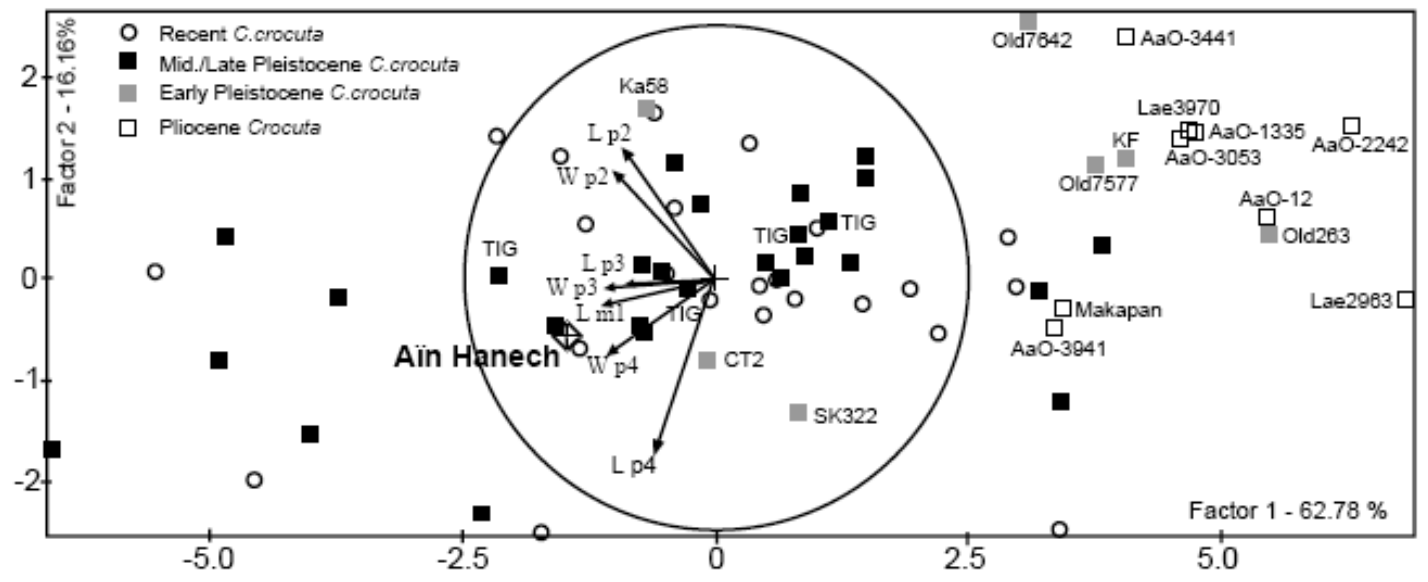

Fig. 1. Principal component analysis on lower teeth measurements of modern C. crocuta. Arrows=projection of the variables on the factor-plane 1-2; circle=correlation circle. Fossil specimens are illustrative. Many measurements are from Turner (1984). AaO=Ahl al Oughlam; CT=Clyde Trading; Ka=Kromdraai A; Lae=Laetoli; Old=Olduvai; SK=Sterkfontein; TIG=Tighenif. 


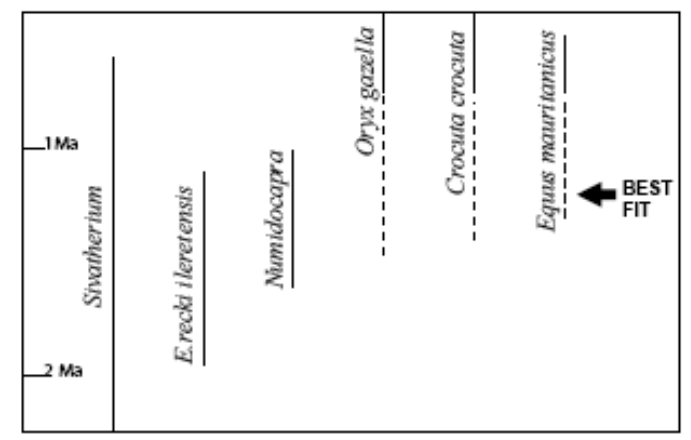

Fig. 2. Range of some of the taxa present at Aïn Hanech. Full lines: known range; dashed lines: likely range.

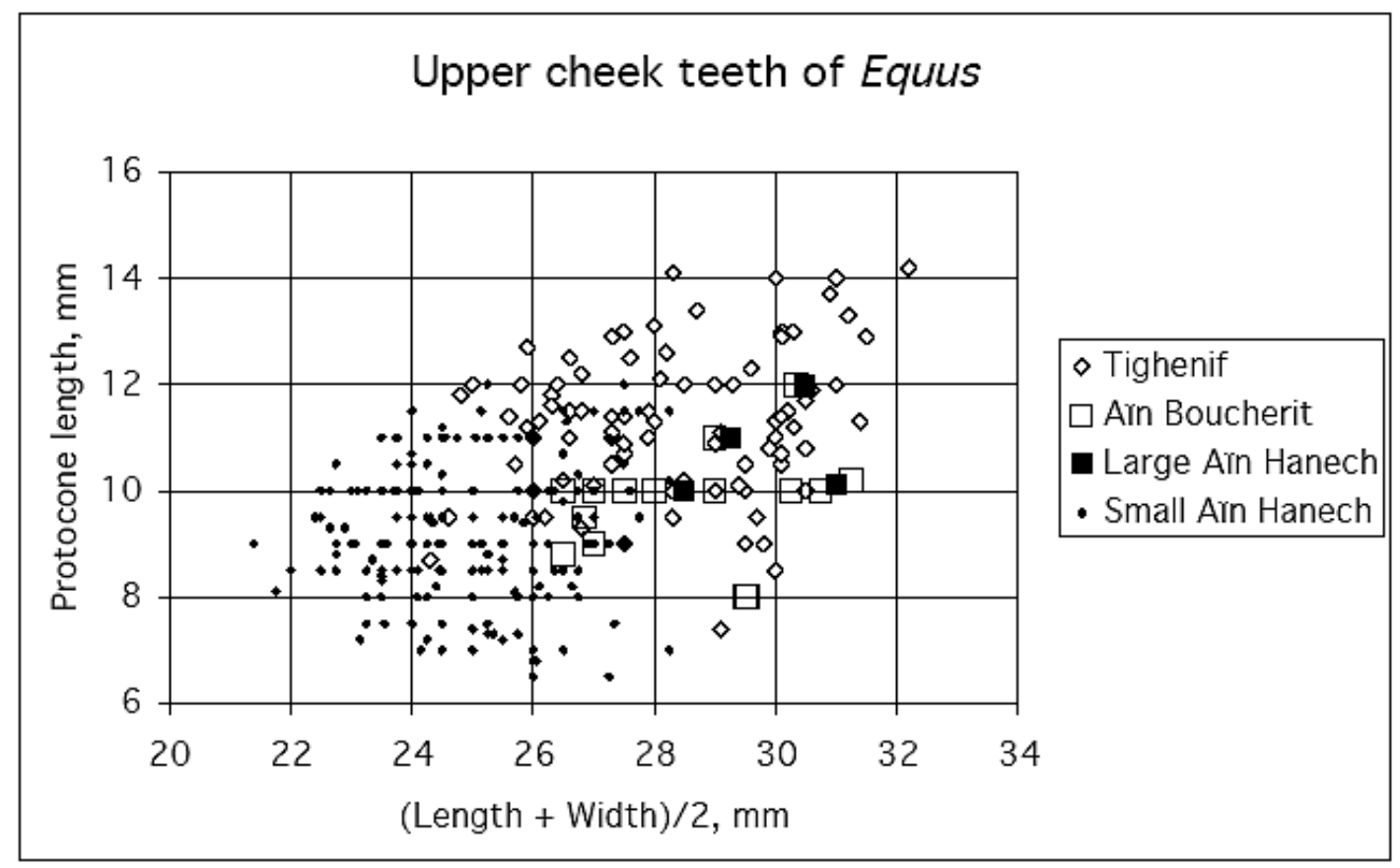

Fig. 3. Scatter diagram of the protocone length vs. the mean occlusal diameter ([length+width $] / 2$ ) in millimeters for Equus upper P3-P4 and M1-M2. Comparison between Tighenif $E$. mauritanicus, Aïn Boucherit E. numidicus, Aïn Hanech E. tabeti (small), and Aïn Hanech Equus sp. (large). 


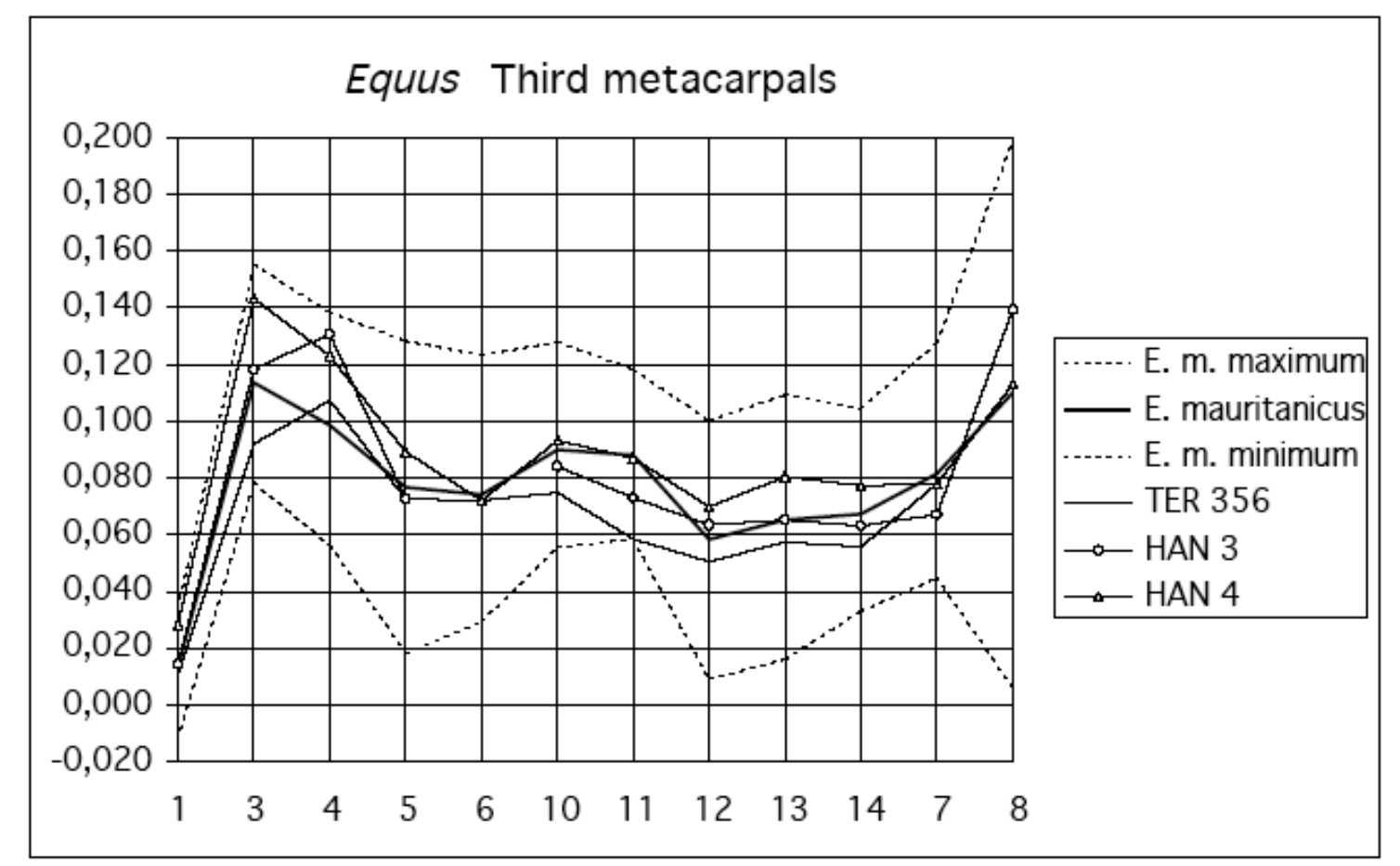

Fig. 4. Ratio diagram of Equus third metacarpals with E. hemionus onager as reference. E. m.: E. mauritanicus. The numbers on the $X$ axis refer to the measurements of Table 1.

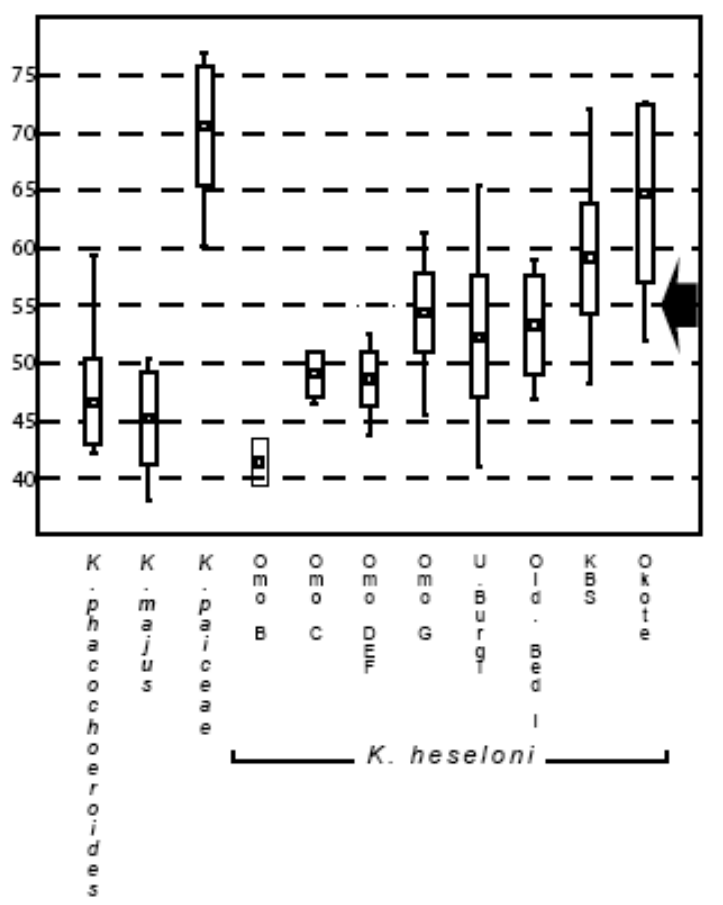

Fig. 5. Lengths (mean 1 standard deviation and range) of the lower M3 of selected Kolpochoerus species. The arrow points to the length of the tooth from Ai"n Hanech. Data are from Cooke (1976), Harris (1983), Hendey and Cooke (1985), and original measurements. 
